\title{
Contextualising regional policy for territorial cohesion in Central and Eastern Europe
}

\author{
BRADLEY LOEWEN ${ }^{1}$
}

\begin{abstract}
This conceptual paper discusses key instruments for territorial cohesion in Central and Eastern Europe (CEE) from a comparative historical analytical perspective amidst the neoliberalisation of EU Regional Policy, which has implications for the production and reinforcement of spatial inequalities in regional development. The neoliberalisation processes unfolding in the different political-institutional contexts of CEE have implications for the movement, transformation and effectiveness of policies such as Regional Policy, complicating the holistic understanding of policy effects. Increasingly neoliberal regional policies across Europe, and in the different path dependent political-institutional contexts of CEE in particular, raise questions about the effectiveness of Regional Policy to achieve territorial cohesion. Comparative historical analysis provides a method of inquiry into path dependent processes shaping institutions and affecting policy outcomes, and is therefore a useful approach for conceptualising regional political-institutional contexts and their implications for Regional Policy. Operational Programmes encompassed in national strategic documents from the Czech Republic, Estonia and Hungary over three programming periods are examined as the key instruments for the implementation of Regional Policy, the comparison of which reveals a difference in perspectives towards the common EU goals of competitiveness and growth as a means of achieving territorial cohesion. The research thus points to the need for deeper comparative understanding of the political-institutional contexts in the three countries in order to identify factors of effective policies and to tailor effective policy solutions to specific regional contexts, a task to be advanced in future studies of Regional Policy and political-institutional contexts of CEE.
\end{abstract}

Keywords: regional policy, cohesion policy, territorial cohesion, neoliberalism, Central and Eastern Europe, Czech Republic, Estonia, Hungary

\section{Introduction}

The post-socialist states of Central and Eastern Europe (CEE), sharing similar socio-political and economic histories, have developed along dramatically different trajectories than their Western neighbours that, even after a decade of European Union (EU) membership, is revealed by large disparities in economic productivity and living standards (ESPON 2014)2. European Regional Policy, primarily influenced by Cohesion Policy and its related funds, has aimed to lead Member States towards 'territorial cohesion,' loosely defined here as multi-scalar balanced territorial development. Territorial cohesion is also associated with "territorial interdependency and solidarity, which can include urban-rural or productive-residential dimensions" (Faludi, A. and Peyrony, J. 2011, p. 5) and relatively new forms of multi-level governance. Despite reiterations between programming

\footnotetext{
${ }^{1}$ Department of Institutional, Environmental and Experimental Economics. Faculty of Economics, University of Economics in Prague; W. Churchill Square 413067 Prague, Czech Republic.

E-mails: bradley.loewen@regpol2.eu

${ }^{2}$ The research leading to these results has received funding from the People Programme (Marie Curie Actions) of the European Union's Seventh Framework Programme FP7/2007-2013/ under REA grant agreement no 607022.
} 
periods, Cohesion Policy has convergence as its primary objective - focusing investment in less developed regions - along with complementary objectives spanning economic and social aspects of regional competitiveness. Altogether, these objectives aim to strengthen and support solidarity and a polycentric spatial development in the EU.

The year 2014 marks a milestone as an anniversary year and as the beginning of a new programming period for Regional Policy guided by the Europe 2020 strategy for "smart, specialised and inclusive growth" (CEC 2010a). As member states conclude their Partnership Agreements and Operational Programmes (OPs) for the 2014-2020 period, it is a timely moment to take stock of how Regional Policy has progressed and how discourses have shaped the recent policymaking agenda and implementation. After a critical review of territorial cohesion and Regional Policy since the accession of CEE countries to the EU, key policy documents are contextualised for the cases of the Czech Republic, Estonia and Hungary across three programming periods. A discussion emerges about the potentials for Regional Policy to support territorial cohesion and thereby tackle spatial inequalities in regional development in the three countries, and the need for deeper understanding of political-institutional contexts in order to tailor context-specific regional policies for this purpose.

\section{Territorial cohesion, spatial inequalities in regional development and neoliberalisation of regional policy}

Political and economic expansion followed by crisis has stimulated much debate over territorial cohesion and Regional Policy during the past decade. A number of high-profile reports concluded that the Lisbon Strategy, of which Cohesion Policy was the primary tool for implementation, failed to close the productivity gap between Europe and industrialised countries (BARCA, F. 2009; CEC 2004, 2005, 2010b). The 2009 financial crisis had the effect of reversing a long trend of economic convergence between Member States as employment rates plummeted outside of Europe's traditional core (CEC 2010b, 2014a,b). In CEE sub-national regional polarisation intensified with uneven implications for regional development (SмIтH, A. and Timár, J. 2010). Thus, despite earlier progress towards territorial cohesion, there is wide consensus that regional disparities persist across Europe, which can be evidenced by various socioeconomic indicators such as competitiveness (ANNONI, P. and DiJKsTRA, L. 2013), GDP per capita (EUROSTAT 2014), and human development (HARDEMAN, S. and Dijkstra, L. 2014).

Figure 1 illustrates the development of GDP per inhabitant in NUTS-2 regions of the Czech Republic, Estonia and Hungary from 1999 to 2011, showing a sharp contrast between the capital regions and their peripheries, in the cases of Czech Republic and Hungary. The similarity of GDP development across peripheral regions of the Czech Republic and Hungary as well as the whole of Estonia, and the impact of the 2009 financial crisis can also be seen.

The increasing spatial inequalities in regional development in Europe are part of a global trend that, under the current dominant discourse of neoliberal theory, increasingly favours the growth of competitive urban centres at the expense of under-developed and structurally weak regions through processes of centralisation and peripheralisation (LANG, T. 2011), demonstrated above by higher growth rates in the capital regions (including faster 'catch-up' in Estonia). While Cohesion Policy has been estimated to have a positive impact on GDP over baseline levels in CEE at the national level (CEC 2014a), regional polarisation continues to be strongly felt in these traditionally peripheral countries. Convergence-divergence tendencies in parallel with polarisation have been detected in CEE NUTS-3 regions from 1990 to 2008, with convergence amongst less productive regions and divergence of more productive regions (MonastiRiotis, V. 2014). 


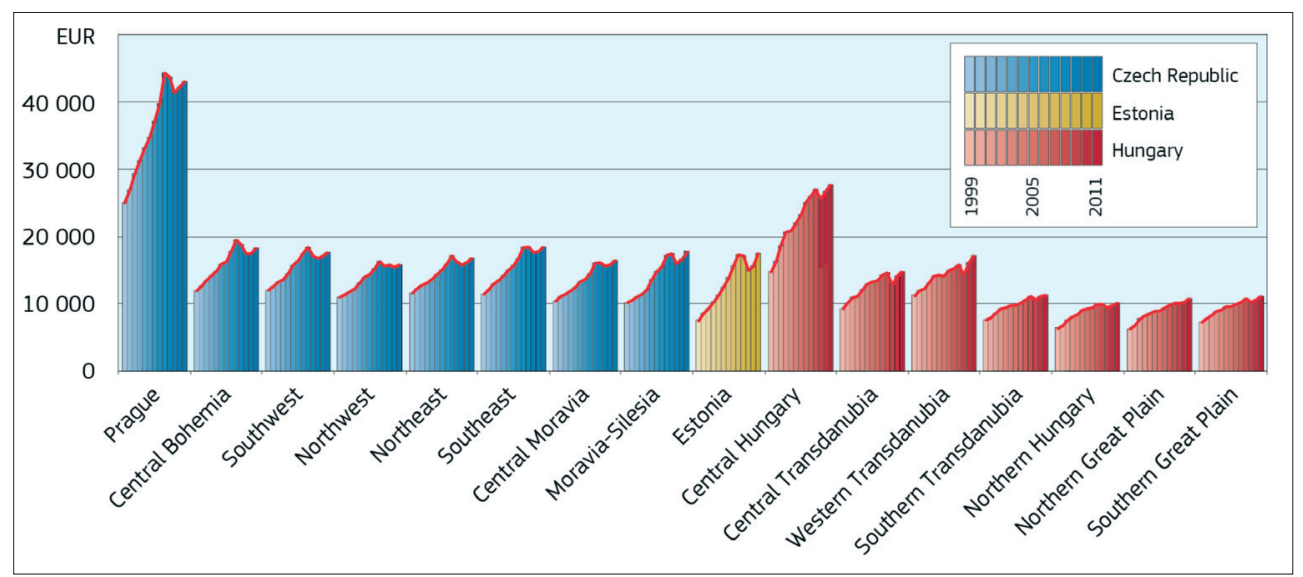

Fig. 1. Gross Domestic Product (GDP) per inhabitant, at current market prices by NUTS-2 regions, 1999-2011 (ESPON 2013; EUROSTAT 2014)

The Third ESPON Synthesis Report summarising a decade of territorial research, pointed to decreasing territorial cohesion due to the growth of urban cores and the decline of rural areas over the programme's lifetime (ESPON 2014). Furthermore, regions of depletion are more concentrated in $\mathrm{CEE}$, where rural areas are also characterised by a higher role of the primary sector and lower accessibility (Copus, A. and Noguera, J. 2010).

While planning the follow-up to the Lisbon Strategy, the effectiveness of Cohesion Policy to somehow maximise growth while achieving convergence was left unclear (FAROLE, T. et al. 2011). Mixed results of the earlier Cohesion Policy prompted reforms for the 2014-2020 period, which, accompanied by the Europe 2020 strategy, would reinforce neoliberal theory as the dominant discourse in European Regional Policy. The milestones of the neoliberalisation of Regional Policy are presented below, beginning with the 1999 European Spatial Development Perspective (ESDP), in which ministers of Member States first endorsed the concept of territorial cohesion. ${ }^{3}$

\footnotetext{
${ }^{3}$ For the current and historical structure of Regional Policy, see: http://ec.europa.eu/regional_ policy en/policy/what/investment-policy/.
}

Regional Policy has evolved to take on an increasingly neoliberal approach since the concept of territorial cohesion was communicated in its (then) most concrete form in the ESDP as the "balanced and sustainable development of the territory of the European Union" (CEC 1999) along with three objectives: economic and social cohesion; environmental conservation and management; and balanced competitiveness in all regions; each corresponding to one of the three pillars of sustainable development established by the United Nations' Brundtland Report (WCED 1987). The objectives of territorial cohesion therefore included an aspect of spatial justice, stipulating spatial reconciliation and safeguarding of regional diversity - elements strongly resistant to normative neoliberal principles. Of significance to CEE countries, the ESDP paid particular attention to structural weaknesses in peripheral areas facing diverse development prospects and consisting of diverse relationships and interdependencies.

The key to the sustainable development of rural regions lies in the development of an independent perspective and the discovery of indigeneous potential and the exchange of experience with other regions, but not in the copying of development perspectives for other regions in the EU (CEC 1999, p. 24). 
Looking towards EU expansion, the ESDP already recognised a "lack of spatial development policies and regional policy instruments and institutions" as well as an absence of regional political and administrative levels in the Accession Countries (i.e. CEE), and, therefore, expected that spatial development processes would not simply replicate those in the traditional core (CEC 1999, p. 49). Critical scholars quickly contested the Europeanisation of spatial planning and the dominance of economic competitiveness put forth in the ESDP (RICHARDSON, T. and Jensen, O.B. 2000). Nevertheless, as territorial cohesion has been promoted, refined and become more intertwined with neoliberal policy since 1999, the normativity of neoliberal principles has dominated policymaking in peripheral areas and thereby limited the array of policy options available.

In 2003 the highly influential Sapir Report prioritised growth through innovation and institutional transformation as a strategy for Europe (SAPIR, A. et al. 2003). The 2009 Barca Report subsequently contributed to a revised Lisbon Strategy, cementing neoliberal values of competitiveness into a place-based strategy (BARCA, F. 2009), and dropping previously implicit notions of spatial justice in territorial cohesion. Moving towards the next programming period, critical scholars called for a context-specific regional policy balanced with increased transparency and fiscal responsibility. On the one hand, Copus, A. and Noguera, J. (2010) offered that for regions to develop their potential, Cohesion Policy should take into account regional conditions associated with narratives of change and local particularities.

The contextualisation of regional policy would necessitate more freedom for regions to deviate from EU and national agendas, especially in CEE where some countries have seen recent recentralisation. On the other hand, Farole, Rodríguez-Pose and Storper recommended that greater conditionality be extended by the EU in order to avoid the potential problems of a decentralised Cohesion Policy (FArole, T. et al. 2011). Others called attention back towards the social dimension to support European integration (LunDVALL, B.Å. and Lorenz, E. 2012), implying a retreat from neoliberalism. The resulting evolution of Cohesion Policy aligned more closely with Europe 2020, shifting priorities from hard infrastructure to soft innovation capacities and exerting tighter controls over the use of funds (CEC 2014a). Nevertheless, Europe 2020 has been criticised for repeating the structural errors of the Lisbon Strategy (González, L. and RubÉn, C. 2013).

The promotion of territorial cohesion within a neoliberal Regional Policy framework presents a critical contradiction between the place-based approach and the normativity of neoliberal principles, since a common set of neoliberal principles neither finds the same application nor produces the same effects within the path dependent political-institutional contexts of regions. After a decade of capitalism STARK and BRUSZT in their common work published in 2001 described the post-socialist condition in CEE in terms of a "diversity of capitalisms" that had emerged in path dependent contexts (p. 1131), recalling Jessop's “actually existing neoliberalisms" (StARK, D. and BRUszt, L. 2001; Jessop, B. 2002). In the wake of the 2009 financial crisis, Brenner, Peck and Theodore postulated that a variegated neoliberalism resulting from successive waves of crisis-induced neoliberal restructuring unfolds unevenly across space and produces "new forms of geo-institutional differentiation" or "inherited politico-institutional arrangements" (BRENNER, N. et al. 2010a, p. 331).

The same authors found that prototypical neoliberal policy transfer between states produces a qualitatively transformed policy in different political-institutional contexts (Brenner, N. et al. 2010b). Therefore, the similarities amongst CEE countries should not be taken for granted when it comes to neoliberalisation processes nor the application of supranational strategies, the effectiveness of which can vary. BARCA, MCCANN and Rodríguez-Pose argued that the place-based approach that took hold in the EU during the 
reformed Lisbon Strategy was conducive to the many existing path-dependent institutional contexts (BARCA, F. et al. 2012).

Nevertheless, the increasingly homogeneous neoliberal regional policy still does not take these into account. A diverse array of appropriate policy responses corresponding to path dependent neoliberal contexts should, therefore, be expected in CEE rather than the narrowing perspective of a (non-existent) pure neoliberalism.

Critical scholars have offered insights into the rise of neoliberalism in other domains of regional development such as New Economic Geography (NEG) and New Regionalism (NR), which are believed to contribute to a depoliticisation of spatial development and the reproduction of uneven spatial development, increasing the vulnerability of lagging regions to the global financial system and disarming regions' political ability to respond to exogeneous events such as the financial crisis (Hadjimichalis, C. 2011; Hadjimichalis, C. and Hudson, R. 2014). Such views incorporated into the research community made it difficult to distinguish progressive from regressive policy (Hadjimichalis, C. and Hudson, R. 2014). In 2004, the neoliberal normativity of the creative economy agendas of place competition and promotion were already being recognised (Gibson, C. and Klocker, N. 2004), and academics have since become intermediaries of creative economies for regional development, unconsciously and uncritically reproducing normative elements (GIBson, C. 2015).

Denial of the problem of spatial inequalities in regional development, therefore, extends from experts and academics to the European Commission, whose evaluations of the Lisbon Strategy and Cohesion Policy interpreted the effects of the financial crisis as the result of macro-economic imbalances and competitiveness problems (CEC 2010b, 2013), without recognising the problematic socio-economic effects of entrenched spatial inequalities and peripheralisation processes accumulating over decades, calling into question intra-European power relations and national interests in the setting of EU policy.
While regional diversity is promoted in Regional Policy, the rhetoric remains limited to the neoliberal narrative of competitiveness and growth that, coupled with Europe 2020, restricts policy options and could work against territorial cohesion by further promoting spatial inequalities in regional development. To understand how these concepts have been represented at the regional level and used to address regional particularities, it is necessary to look within individual Member States. National documents for Regional Policy (including Operational Programmes) from the Czech Republic, Estonia and Hungary are next compared to differentiate between national perspectives.

\section{Comparative analysis: Regional Policy in the Czech Republic, Estonia and Hungary}

As the case has been made above for decreasing territorial cohesion in CEE countries, attention will next be directed to Regional Policy as applied in the CEE context to ascertain similarities and differences in the political-institutional contexts in which Regional Policy is delivered. The above mentioned critiques of neoliberalism in Regional Policy and related fields point to hidden differences in national contexts and the need to investigate beyond the normative elements of EU Regional Policy, as reproduced in national and regional policies, in order to uncover national discourses and political-institutional contexts with implications for policy effectiveness.

Programmes in the Czech Republic, Estonia and Hungary are investigated from a comparative analytical approach along the lines of Comparative Historical Analysis within the field of New Institutionalism, which examines a small number of cases against a theoretical backdrop in order to challenge prior beliefs about the cases (Goldstone, J.A. 2003), focusing on processes over time and the use of systematic and contextualised comparison (Mahoney, J. and Rueschemeyer, D. 2003).

The three country cases herein are often grouped together as 'post-socialist', thereby 
suppressing notions of difference, and are recipients of EU policy intended for homogeneous application across Member States. The forthcoming analysis examines the guiding national strategic documents of Regional Policy from three programming periods, encompassing Operational Programmes, to uncover differences between the three countries that also have potential implications for policy effectiveness.

Pre-accession support, Regional Policy and Operational Programmes

Agenda 2000 laid out the EU's enlargement strategy in response to a high volume of membership applications from CEE including the Czech Republic, Estonia and Hungary (CEC 1997). Cohesion was envisioned to be of great importance in an enlarged Union, and funding through the PHARE programme and Agenda 2000 prioritised upgrading transportation and environmental infrastructure and institutions, investments that were considered vital for the realisation of political and economic advantages in an enlarged Union. Therefore, the process of territorial cohesion with a long-term focus on outward-looking competitiveness was in motion even before the 2004 enlargement. Following their accession, financial support was provided by Structural and Cohesion Funds, which have continued to drive investments for territorial cohesion in Member States through Regional Policy.

Operational Programmes (OPs) are viewed here as the implementing instruments of Regional Policy and for delivering Cohesion Policy into national contexts. The Czech Republic, Estonia and Hungary were funded for OPs for the remainder of the 2000-2006 (i.e. 2004-2006), 2007-2013 and 2014-2020 (on-going) periods. The strategies and thematic contents of OPs can be identified by examining their EU-negotiated parent national strategic documents for the allocation of investment funds. In 2004-2006, Community Support Frameworks (CSFs) outlined five OPs in each of the Czech Republic and
Hungary. Estonia had a single national OP for comparison. In 2007-2013, the number of OPs (not to mention cross-border co-operations) proliferated: six national and eight regional OPs in the Czech Republic (including one national and one regional Objective 2 Programme); two regional OPs in Estonia; and seven national and seven regional OPs in Hungary; all of which stemmed from the EU-negotiated documents, National Strategic Reference Frameworks (NSRFs). The 20142020 period was simplified, with only national OPs in the roster (again, excluding cross-border programmes), developed under the guiding national Partnership Agreements (PAs). Table 1 presents the instruments reviewed in the three-country comparison.

\section{Development of Regional Policy in national contexts}

The following sections summarise and compare Regional Policy programmes between the Czech Republic, Estonia and Hungary. In the 2004-2006, 2007-2013 and 2014-2020 programming periods the three countries shared a similar economic situation of being small, open and export-oriented economies in the context of increased global trade liberalisation, with implications for regional disparities. The objectives across periods have been fairly continuous and the content of programmes across periods differs to a very little extent, in accordance with the reproduction of EU policy elements. Nevertheless, the comparison suggests some differentiation between the country perspectives as well as some convergence of these perspectives moving towards the 2014-2020 period, possibly due to the streamlining influence of Europe 2020.

Table 2 highlights key principles in national strategies in Regional Policy instruments, thereby demonstrating variation in the representation of neoliberal elements, and is followed by further description of key messages from each country. This raises the questions of how these variations may be connected to the successful or unsuccessful transfer of EU Regional Policy into the national contexts 
Table. 1. Regional Policy instruments reviewed in the Czech Republic, Estonia and Hungary from the 2004-2006, 2007-2013 and 2014-2020 programming periods

\begin{tabular}{|c|c|c|c|c|}
\hline Programming period & Instrument & Czech Republic & Estonia & Hungary \\
\hline \multirow{4}{*}{ 2004-2006 } & $\begin{array}{l}\text { Community Support } \\
\text { Framework }\end{array}$ & Yes & No & Yes \\
\hline & $\begin{array}{l}\text { Operational Programme } \\
\text { (National) }\end{array}$ & \multirow{2}{*}{5} & 1 & 5 \\
\hline & $\begin{array}{l}\text { Operational Programme } \\
\text { (Multiregional) }\end{array}$ & & - & - \\
\hline & $\begin{array}{l}\text { Operational Programme } \\
\text { (Regional) }\end{array}$ & 1 & - & - \\
\hline \multirow{3}{*}{$2007-2013$} & $\begin{array}{l}\text { National Strategic Reference } \\
\text { Framework }\end{array}$ & Yes & Yes & Yes \\
\hline & $\begin{array}{l}\text { Operational Programme } \\
\text { (National) }\end{array}$ & 6 & 2 & 7 \\
\hline & $\begin{array}{l}\text { Operational Programme } \\
\text { (Regional) }\end{array}$ & 8 & - & 7 \\
\hline \multirow{2}{*}{ 2014-2020 } & Partnership Agreement & Yes & Yes & Yes \\
\hline & $\begin{array}{l}\text { Operational Programme } \\
\text { (National) }\end{array}$ & 7 & 1 & 6 \\
\hline
\end{tabular}

in CEE, and what the subsequent effects of regional policies on spatial inequalities and territorial cohesion might be.

\section{Czech Republic}

The 2004-2006 strategy of the Czech Republic was described as "sustainability based on competitiveness" (MMR 2003, p. 61), supporting objectives of the Lisbon Strategy while focusing on the country's relative performance within the EU for achieving territorial cohesion. Despite regional disparities, achieving sustainable economic development depended on taking advantage of the Prague agglomeration and its spill-over effects, developing other major growth poles, and upgrading transport infrastructure as a precondition for competitiveness and growth: "the main aim of the Structural Funds is ... to finance interventions which can be expected to have a positive effect on long-run productivity gains and employment creation" ( $p$. 55). Horizontal objectives including environ- mental standards, social inclusion and balanced development of regions were included in each OP. The latter objective addressing territorial cohesion was described as "decreasing the negative impacts of unbalanced economic growth" (p. 68), thereby tackling the problem of spatial inequalities.

In the 2007-2013 NSRF attention was drawn to the risks of diminishing global cost competitiveness, lagging productivity and institutional barriers impeding the business climate (MMR 2007). Cohesion was represented both between regions and in relation to the EU, which continued the existing contradiction between convergence and competitiveness objectives: "There are also priorities in place with objectives in compliance with the Lisbon Strategy in support of the competitiveness of regions with the highest growth potential, whose stimulation will contribute to the CR's convergence to the European av-

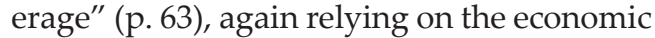
core to lift all regions, which could intensify spatial inequalities. Nevertheless, growing regional disparities in unemployment were 


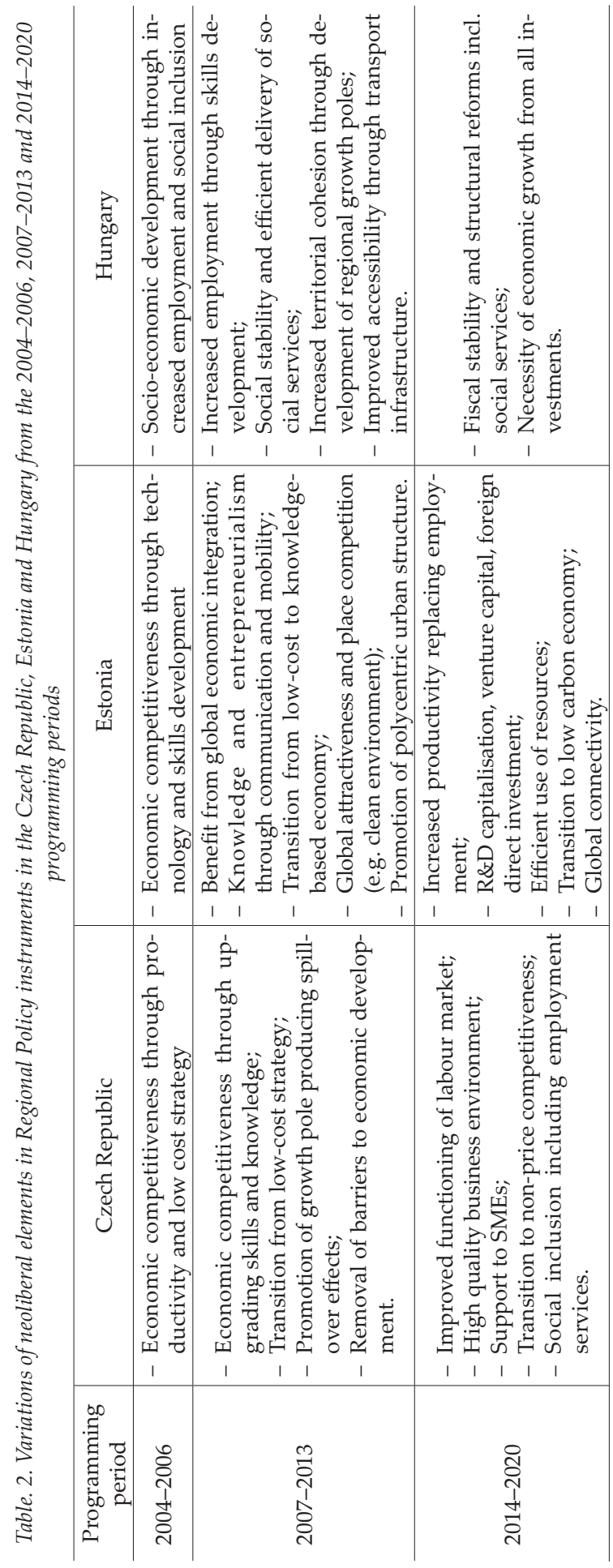

noted, as well as the problems of transport deficiencies and bottlenecks, e.g. in the TEN-T network, considered to hamper flows between the East and West due to the Czech Republic's central position in the EU.

Spatial polarisation and fragmentation continued to be an inhibiting factor to the development of lower-order growth poles and a cohesive territorial development. Regional trajectories covered a range from "undergoing rapid development" to "having low growth dynamics" and being "on the decline" (p. 27). Business incentives to SMEs were targeted to help this large segment of the economy achieve its growth potential, especially in underdeveloped regions. Social cohesion through inclusion and improvements to public administration were also specified.

The 2014-2020 Partnership Agreement was designed for maximum coherence with the Europe 2020 Strategy (with associated targets) and related national policies. Previous priorities were renewed, with the strategic objectives of "developing a high quality business environment" and "providing an inclusive society" (MMR 2014, p. 118). Increasing the quality of education, core infrastructure and public institutions were listed as conditions for renewed economic growth, and investments were targeted to structurally weak regions to address traditional industries and growing long term social exclusion.

\section{Estonia}

Estonia's single OP for the 2004-2006 period focused on human resources development for economic competitiveness, but with a distinct specialisation on ICT. Skills and development was addressed by matching educational opportunities to demands of the labour market. Disparities within the region were de- 
scribed in terms of GDP contributions between Tallinn and other counties (NUTS-3 regions), demonstrating a strong core-periphery duality. Without a CSF, Estonia's programme aligned with its own National Development Plan, and participation in Regional Policy was comparatively simple. Nevertheless, $e x$ post evaluations found that the "centralised implementation and prioritisation of goals left the regional perspective as a subsidiary aim" (Applica-Ismeri Europa-wiiw 2010, p. $3)$. Setting targets within the NUTS-2 region was not required, so the OP was more free to pursue national interests, of which spatial polarisation was still a concern.

The 2007-2013 NSRF projected a global and entrepreneurial spirit of Estonia, poised to benefit from increasing global trade liberalisation, as its position as a small, open and integrated economy was firmly established. The headline objective of "fast and sustainable development" (Republic of Estonia 2007, p. 65) aimed to promote open mobility and communication for knowledge transfer and entrepreneurialism: “...we also have an opportunity to win from the global expansion of labour market assumed that people return to Estonia richer with one [sic] experience" (p. 15). Technological advancement and opportunities for foreign direct investment were viewed as a means to escape its diminishing role as a low-cost labour provider: "the fast and expansive adoption of new technologies ... and updating of business and operational models ... are extremely important" (p. 18). Neoliberal notions of attractiveness and place competition were also promoted through welfare reforms, environmental sustainability, and cultural potentials of the periphery. "Decreasing domestic regional balance" (p. 24) from uneven economic growth and urban-rural migration was addressed through promoting the development of a polycentric urban structure, elevating the representation of territorial cohesion in the national strategy. Nevertheless, the capital region continued to be a major driver of economic restructuring and attraction, entrenching spatial inequalities.
In the 2014-2020 PA Estonia looks for increased macro-economic stability following the global credit crunch to reduce its vulnerability as an open economy (Republic of Estonia 2014). The country is preparing for a nominal decline in employment due to an aging population, which determines its economic strategy - "economic growth can only be driven by productivity and investments supporting it" (p. 6) - and focuses on high value-added levels of the economy, capitalisation of R\&D, attraction of venture capital, and more efficient use of natural resources. Estonia further reinforces its international outlook by prioritising global connectivity for economic growth: "Participation in global value chains unavoidably requires the existence of high quality connections," and, "the impact of flight connections on GDP growth can range from $4-7 \%$ " (p. 20).

The strategy points to decreased albeit large regional economic disparities from 2005-2012, suggesting positive movement for territorial cohesion - "regional differences in GDP relative to population between Harju and Tartu Counties ... and all other regions ... have decreased" (p. 42) - although significant internal migration to the core urban areas of Tallinn and Tartu have occurred since the 2008 financial crisis (RAAgmAA, G. and SteAd, D. 2013). The strategy states that "all regions located outside of the urban areas of Tallinn and Tartu need additional attention in accordance with their specific problems," (p. 45) evidenced by limited employment and commuting possibilities.

\section{Hungary}

The Hungarian CSF highlighted the intensification of pre-existing regional disparities arising from market liberalisation and economic restructuring (Republic of Hungary, 2003). On the whole, the strategy demonstrated a strong social perspective amidst stable political and economic conditions, positioning human development as the primary means towards achieving territorial cohesion: 
"Hungary must give renewed policy focus to strengthening its overall level of development in order to move towards convergence with the level of the socio-economic development of the EU" (p. 68). The inclusion of "socio-" in this overall strategy is palpable. "Improving the use of human resources," (p. 68) took the second place objective, although it was also a prominent strategy for the first objective, economic competitiveness. Lowerorder objectives included environment, basic infrastructure and balanced territorial development. Thus, the dominant theme of the CSF was inclusive human development to improve employment, which suffered due to substantial withdrawal from the labour market. The presence of high quality educational institutions was seen as a potential resource for improving employment in the less developed regions of the East, albeit amidst struggling R\&D capacities characterised by lack of knowledge transfer, out-dated technologies and underinvestment. Other social topics covered, such as healthcare, inclusion and equal opportunity, demonstrated a strongly social perspective.

The 2007-2013 programme once again called for growth through increased employment with an enhanced global economic dimension, with a condition of respecting social values: "[We] need a brave and creative economic development concept embracing issues of employment as well that respects both the satisfaction of social demands and macro-economic stability" (Republic of Hungary 2007, p. 1). In this way, economic performance was secondary and conditional with respect to social cohesion, a resistant stance to the neoliberal norm. Cohesion and Structural Funds were framed as an opportunity for the "renewal of society" (p. I). Institutional reform was framed for the efficient delivery of social welfare rather than economic development. Regional disparities and internal contradictions were still high, and spatial polarisation was addressed through support for developing regional growth poles and harnessing endogeneous potentials to develop comparative advantages.
Following a period of fiscal consolidation after the financial crisis - itself necessarily a neoliberal condition for economic growth - Hungary considered itself well-positioned to benefit from Cohesion and Structural Funds (Republic of Hungary 2013). The 2014-2020 PA continued to focus on fiscal policy for strong macro-economic conditions through targeted actions: "[These] funds can only result in additional economic growth in Hungary if they are used in a more targeted and simple manner compared to the previous period" (p. 10), but retreated somewhat from the markedly social stance of previous programmes: "The development programmes which are not directly of an economic nature must be engineered in a way that they can ... contribute to the goal of growth" (p. 11). Therefore, the PA marks a shift and perhaps exemplifies the most drastic neoliberalisation of policy of the three countries studied.

Regarding spatial polarisation it was believed that both old and new processes producing regional disparities, including microregional, needed support at a lower level than NUTS-2 to be successful. The resulting programme exhibited a broader, streamlined set of development priorities corresponding to Europe 2020, showing growing similarity to the other countries reviewed. Low employment was still one of the most serious concerns hampering growth.

\section{Contextualising further research}

The above sheds light on variations that can be produced within the EU streamlining process that appears to impose common policy onto different political-institutional contexts, raising further questions about these national contexts and their abilities to transfer policy. The content of the national documents reviewed is admittedly light and optimistic, especially considering that over the three programming periods, regional inequalities in CEE have worsened and the European economy has faced its biggest challenges in decades. Nevertheless, the strategies outlined 
therein demonstrate variation in the pursuit of competitiveness and growth amidst increasingly neoliberal supranational policy.

The Czech Republic's focus on catching up with European-average productivity through cost-competitiveness and reduced barriers to business contrasts with Hungary's focus on increasing labour market participation through developing human resources and Estonia's leap into advanced global niche markets. Such variations in the approaches to the normative principles of competitiveness and growth recall the previously discussed notions of 'actually existing' and 'variegated' neoliberalisms (Jessor, B. 2002; Brenner, N. et al. 2010a), and suggest the possibility of further variations - that should be investigated - once Regional Policy is put into national and regional contexts. RAAGMAA and STEAD wrote that after accession CEE countries practiced a combination of previous behaviour, new EU rules, and local agendas leading to double standards in policymaking (RaAgmaA, G. and Stead, D. 2013).

Furthermore, MonAstiriotis stated that national economic contexts play a role in the convergence process (MonastiRIotis, V. 2014). Therefore, the path dependent political-institutional structures in CEE almost certainly carry remnants of previous regimes more than two decades after liberalisation that are influencing emerging forms of neoliberalism and have implications for Regional Policy, territorial cohesion, and spatial inequalities in regional development.

Moving forward, it becomes critical to further understand specific political-institutional contexts alongside policies in order to address some key questions raised by this paper: How has Regional Policy been transferred to CEE and transformed through the transfer process? How has the transferred policy addressed the EU concept of cohesion and real spatial inequalities in different national contexts? And ultimately, What factors of regional policy are particularly effective for promoting territorial cohesion in the CEE? The answers to these questions will help to elucidate Monastiriotis' relationships between national economic contexts and convergence in order to form specific policy recommendations for CEE. Moreover, the identification of key factors of successful regional policies in CEE can benefit Regional Policy as a whole by further developing the place-based approach and subsequently informing new iterations of policy instruments.

\section{Conclusion}

The preceding comparative analysis has highlighted different national perspectives in the cases of the Czech Republic, Estonia and Hungary towards the neoliberal principles of competitiveness and growth promoted by Regional Policy. Critical scholars have responded to the neoliberalisation of Regional Policy and its negative effects by suggesting alternatives, from a re-politicisation and democratisation of policy to a reconsideration of discarded alternate forms of regionalism (e.g. welfare regionalism) (Hadjimichalis, C. and Hudson, R. 2014), or a refocusing of policy from convergence to underdevelopment (FAROLE, T. et al. 2011). In any case, a deeper comparative understanding of national and regional political-institutional contexts is required to move beyond the neoliberal rhetoric of Regional Policy that is reproduced in national documents, and to ultimately determine the factors of successful regional policies for context-specific policy recommendations, of which this study took a first step.

Peck, Theodore and Brenner argued that critical analysis needs to extend beyond concerns about what policies achieve, "to consider the manner in which they move, how cross-jurisdictional reform trajectories are constructed, and how the over-all pattern of policy making varies over time and space" (PeCK, J. et al. 2012, p. 278). It will be critical to consider these aspects in the quest for contextualised regional policymaking in CEE. Comparative Historical Analysis within the field of New Institutionalism offers an approach conducive to this task. Despite an accumulation of knowledge during the 


\section{REFERENCES}

Annoni, P. and Dijkstra, L. 2013. EU Regional Competitiveness Index: RCI 2013. Luxembourg, European Commission, Joint Research Centre, Publications Office of the European Union, $160 \mathrm{p}$.

Applica-Ismeri Europa-wiiw 2010. Ex Post Evaluation of Cohesion Policy Programmes 2000-2006 financed by the European Regional Development Fund in Objective 1 and 2 Regions: Working package 1: Coordination, analysis and synthesis. Task 4: Development and achievements in Member States: Estonia. Applica-Ismeri Europawiiw Consortium. 20 p.

Barca, F. 2009. An Agenda for a Reformed Cohesion Policy: A Place-Based Approach to Meeting European Union Challenges and Expectations. Independent report prepared at the request of the European Commissioner for Regional Policy. Brussels, Danuta Hübner European Commission, $244 \mathrm{p}$.

Barca, F., McCann, P. and Rodríguez-Pose, A. 2012. The case for regional development intervention: Place-based versus place-neutral approaches. Journal of Regional Science 52. (1): 134-152.

Brenner, N., Peck, J. and Theodore, N. 2010a. Variegated neoliberalization: Geographies, modalities, pathways Global Networks 10. (2): 182-222.

Brenner, N., Peck, J. and Theodore, N. 2010b. After Neo-liberalization? Globalizations 7. (3): 327-345.

CEC 1997. Agenda 2000 - For a Stronger and Wider Europe. Supplement 5/97 to the Bulletin of the European Union. Luxembourg, Office for Official Publications of the European Communities, $138 \mathrm{p}$.

CEC 1999. ESDP - European Spatial Development Perspective: Towards Balanced Sustainable Development of the Territory of the European Union. Luxembourg, Office for Official Publications of the European Communities, $87 \mathrm{p}$.

CEC 2004. Facing the challenge: The Lisbon strategy for growth and employment. Report from the High Level Group. Luxembourg, Office for Official Publications of the European Communities, $51 \mathrm{p}$.

CEC 2005. Communication to the Spring European Council - Working together for growth and jobs - A new start for the Lisbon Strategy. Communication from President Barroso in agreement with VicePresident Verheugen \{SEC (2005) 192\}, \{SEC (2005) 193\}. Brussels, European Commission, $31 \mathrm{p}$.

CEC 2010a. EUROPE 2020: A strategy for smart, sustainable and inclusive growth \{COM (2010) 2020 final\}. Brussels, European Commission, $35 \mathrm{p}$.

CEC 2010b. Commission Staff Working Document: Lisbon Strategy Evaluation Document. \{SEC (2010) 114 final\}. Brussels, European Commission, $21 \mathrm{p}$.

CEC 2013. Expert evaluation network on the performance of Cohesion policy 2007-2013. Synthesis of National Reports 2013. Brussels, European Union, 110 p.

CEC 2014a. Investment for jobs and growth: Promoting development and good governance in EU regions and cities. Sixth report on economic, social and territorial cohesion. Luxembourg, Publications Office of the European Union, 334 p.

CEC 2014b. 2014/99/EU: Commission Implementing Decision of 18 February 2014 setting out the list of regions eligible for funding from the European Regional Development Fund and the European Social Fund and of Member States eligible for funding from the Cohesion Fund for the period 2014-2020. Notified under document C (2014) 974. Official Journal of the European Union L 50. (22): $13 \mathrm{p}$.

Copus, A. and Noguera, J. 2010. A Typology of Intermediate and Predominantly Rural NUTS 3 Regions. EDORA Scientific Working Paper No. 24. EDORA Final Report, Annex 1 (Part C: Scientific Working Papers). ESPON 2013 Programme, Luxembourg, Publications Office of the European Union, 732-778.

ESPON 2013. Gross Domestic Product per capita in PPS, 1999-2008 (GDPPPS_CAP). ESPON M4D, ESPON Database. ESPON 2013 Programme, Publications Office of the European Union, Luxembourg, $54 \mathrm{p}$.

ESPON 2014. Territories finding a New Momentum: Evidence for Policy Development, Growth and Investment. Third ESPON Synthesis Report: ESPON results by July 2014. ESPON 2013 Programme, Luxembourg, Publications Office of the European Union, $66 \mathrm{p}$.

EUROSTAT 2014. Gross Domestic Product (GDP) per inhabitant, in purchasing power standard (PPS), by NUTS 2 regions, 2007-2011. [Online data codes: nama_r_e2gdp].

Faludi, A. and Peyrony, J. 2011. Cohesion Policy Contributing to Territorial Cohesion - Future Scenarios. Refereed article No. 43, European Journal of Spatial Development, $21 \mathrm{p}$.

Farole, T., Rodríguez-Pose, A. and Storper, M. 2011. Cohesion Policy in the European Union: Growth, Geography, Institutions. Journal of Common Market Studies 49. (5): 1089-1111.

Gibson, C. 2015. Negotiating Regional Creative Economies: Academics as Expert Intermediaries Advocating Progressive Alternatives. Regional Studies 49. (3): 476-479.

Gibson, C. and Klocker, N. 2004. Academic publishing as 'creative' industry, and recent discourses of 'creative economies': some critical reflections. Area 36. $423-434$.

Goldstone, J.A. 2003. Comparative Historical Analysis and Knowledge Accummulation in the Study of Revolutions. In Comparative Historical Analysis in the Social Sciences. Eds.: Mahoney, J. and Rueschemeyer, D. New York, Cambridge University Press, 41-90.

González, L. and Rubén, C. 2013. The “Europe 2020 Strategy" as a vision to emerge from the crisis: an overall interpretation. In European Regions in 
the Strategy to Emerge from the Crisis: the Territorial Dimension of the "Europe 2020". Eds.: RubÉn, C., González, L. and CarriL, V.P. Cursos e Congresos $\mathrm{n}^{\mathrm{o}}$ 222. Santiago de Compostela, Servizo de Publicacións da Universidade de Santiago de Compostela, 17-27.

Hadjimichalis, C. 2011. Uneven geographical development and socio-spatial justice and solidarity: European regions after the 2009 financial crisis. European Urban and Regional Studies 18. (3): 254-274.

Hadjimichalis, C. and Hudson, R. 2014. Contemporary Crisis Across Europe and the Crisis of Regional Development Theories. Regional Studies 48. (1): 208-218.

Hardeman, S. and Dijkstra, L. 2014. The EU Regional Human Development Index. Luxembourg, Publications Office of the European Union, 102 p.

Jessop, B. 2002. Liberalism, Neo-Liberalism and Urban Governance: A State Theoretical Perspective. Antipode 34. (3): 452-472.

LANG, T. 2011. Regional development issues in Central and Eastern Europe: shifting research agendas from a focus on peripheries to peripheralisation? In Geography in Visegrad and Neighbour Countries. Eds.: Erôss, Á. and Karácsonyi, D. Budapest, Geographical Research Institute HAS, 57-64.

Lundvall, B.A. and Lorenz, E. 2012. From the Lisbon Strategy to Europe 2020. In Towards a Social Investment Welfare State? Ideas, Policies and Challenges. Eds.: Morel, N., Palier, B. and Palme, J. Bristol, Policy Press, 333-352.

Mahoney, J. and Rueschemeyer, D. 2003. Comparative Historical Analysis: Achievements and Agendas. In Comparative Historical Analysis in the Social Sciences. Eds.: Mahoney, J. and Rueschemeyer, D. New York, Cambridge University Press, 3-38.

MMR 2003. Community Support Framework: Czech Republic 2004-2006. CCI: 2003CZ161CC001. Prague, Ministry of Regional Development, The Czech Republic, $162 \mathrm{p}$.

MMR 2007. National Strategic Reference Framework of the Czech Republic 2007-2013. Prague, Ministry of Regional Development, The Czech Republic, $150 \mathrm{p}$.

MMR 2014. Partnership Agreement for the Programming Period 2014-2020: Czech Republic. Prague, Ministry of Regional Development, The Czech Republic, $237 \mathrm{p}$.

Monastiriotis, V. 2014. Regional Growth and National Development: Transition in Central and Eastern Europe and the Regional Kuznets Curve in the East and the West. Spatial Economic Analysis 9. (2): 142-161.
Peck, J., Theodore, N. and Brenner, N. 2012. Neo-liberalism resurgent? Market rule after the Great Recession. South Atlantic Quarterly 111. (2): 265-288.

RangmaA, G. and Stead, D. 2013. Spatial Planning in the Baltic States: Impacts of European Policies. European Planning Studies 22. (4): 671-679.

Republic of Estonia 2007. Estonian National Strategic Reference Framework 2007-2013. Tallinn. Republic of Estonia, $145 \mathrm{p}$.

Republic of Estonia 2014. Partnership Agreement for the use of European Structural and Investment Funds 2014-2020. 2014EE16M8PA001. Tallinn, Republic of Estonia, $210 \mathrm{p}$.

Republic of Hungary 2003. Community Support Framework 2004-2006: Republic of Hungary: Objective 1 of the Structural Funds. CCI: 2003HU161CC001. Budapest, Republic of Hungary, 188 p.

Republic of Hungary 2007. The New Hungary Development Plan: National Strategic Reference Framework of Hungary 2007-2013: Employment and Growth. Budapest, Republic of Hungary, 200 p.

Republic of Hungary 2013. Hungarian Partnership Agreement, for the 2014-2020 programming period: Final draft. Budapest, Republic of Hungary, 188 p.

Richardson, T. and Jensen, O.B. 2000. Discourses of Mobility and Polycentric Development: A Contested View or European Spatial Planning. European Planning Studies 8. (4): 503-520.

Sapir, A., Aghion, P., Bertola, G., Hellwig, M., PisaniFerry, J., Rosati, D., Viñals, J. and Fallace, H. 2003. An Agenda for a Growing Europe: Making the EU Economic System Deliver. Brussels, Independent High Level Study Group. Access: http://www. swisscore.org/Policy\%20docs/general_research/sapir_report_en.pdf.

Sмith, A. and Timár, J. 2010. Uneven transformations: Space, economy and society 20 years after the collapse of state socialism. European Urban and Regional Studies 17. (2): 115-125.

Stark, D. and Bruszt, L. 2001. One way or multiple paths? For a comparative sociology of East European capitalism. American Journal of Sociology 106. (4): 1129-1137.

WCED 1987. Our Common Future. Report on the World Commission of Environment and Development. New York, United Nations, 383 p. 


\title{
Ukraine in Maps
}

\author{
Edited by: Kocsis, K., Rudenko, L. and Schweitzer, F.
}

\author{
Institute of Geography National Academy of Sciences of Ukraine \\ Geographical Research Institute Hungarian Academy of Sciences. \\ Kyiv-Budapest, 2008, 148 p.
}

Since the disintegration of the USSR, the Western world has shown an ever-growing interest in Ukraine, its people and its economy. As the second-largest country in Europe, Ukraine has a strategic geographical position at the crossroads between Europe and Asia. It is a key country for the transit of energy resources from Russia and Central Asia to the European Union, which is one reason why Ukraine has become a priority partner in the neighbourhood policy of the EU. Ukraine has pursued a path towards the democratic consolidation of statehood, which encompasses vigorous economic changes, the development of institutions and integration into European and global political and economic structures. In a complex and controversial world, Ukraine is building collaboration with other countries upon the principles of mutual understanding and trust, and is establishing initiatives aimed at the creation of a system that bestows international security.

This recognition has prompted the Institute of Geography of the National Academy of Sciences of Ukraine (Kyiv) and the Geographical Research Institute of the Hungarian Academy of Sciences (Budapest) to initiate cooperation, and the volume entitled "Ukraine in Maps" is the outcome of their joint effort. The intention of this publication is to make available the results of research conducted by Ukrainian and Hungarian geographers, to the English-speaking

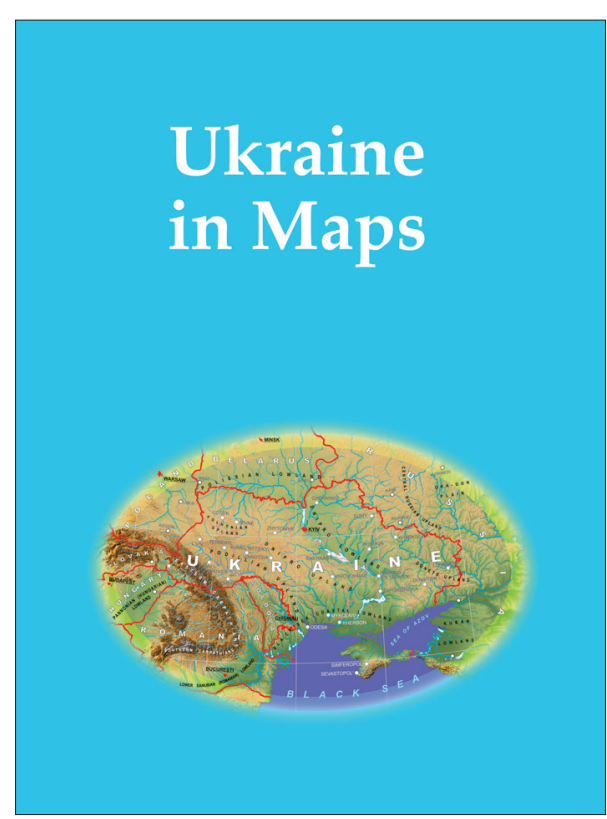
public. This atlas follows in the footsteps of previous publications from the Geographical Research Institute of the Hungarian Academy of Sciences. Similar to the work entitled South Eastern Europe in Maps (2005, 2007), it includes 64 maps, dozens of figures and tables accompanied by an explanatory text, written in a popular, scientific manner. The book is an attempt to outline the geographical setting and geopolitical context of Ukraine, as well as its history, natural environment, population, settlements and economy. The authors greatly hope that this joint venture will bring Ukraine closer to the reader and make this neighbouring country to the European Union more familiar, and consequently, more appealing.

Price: EUR 35.00

Order: Geographical Institute RCAES HAS Library

H-1112 Budapest, Budaörsi út 45.

E-mail: magyar.arpad@csfk.mta.hu 